\title{
SUBSURFACE APPLICATION OF THE BACTERIUM SERRATIA ENTOMOPHILA FOR THE CONTROL OF GRASS GRUB IN CANTERBURY
}

\section{T.A. JACKSON ${ }^{1}$, J.F. PEARSON ${ }^{1}$, T.M. BROAD ${ }^{1}$, M. O'CALLAGHAN ${ }^{1}$ and H.K. MAHANTY ${ }^{2}$.}

${ }^{1}$ MAFTech, P.O. Box 24, Lincoln, Canterbury.

${ }^{2}$ Dept of Plant and Microbial Sciences, University of Canterbury.

\section{SUMMARY}

The bacterium Serratia entomophila was applied by subsurface application in autumn 1987 for control of grass grub in seven trials at four locations throughout Canterbury. The bacteria were successfully established in the soil and disease levels averaging $20 \%$ were recorded in May, resulting in a 55\% reduction in prepupal larvae and pupae by September/October. Populations 1 year after application remained low in treated plots and diseased larvae were found in both treated and untreated plots.

\section{INTRODUCTION}

Amber disease of grass grub was first recognised and the causative bacterium isolated in 1981 (Trought et al 1982). The bacterium has since been characterised (Stucki et al 1984) and identified as a new species Serratia entomophila (Grimont et al 1988). Recently the bacterium has been under investigation as a potential inundative biological control agent for grass grub. Positive results have been reported from small plot trials (Jackson et al 1986) where the bacteria were applied as a soil drench. The soil drench technique, however, is clearly inappropriate for large scale applications. Last year we reported on an evaluation of application methods for placement of the bacteria in soil (O'Callaghan et al 1987). Surface and subsurface turf treatments have been further tested on grass grub populations confirming the superiority of the subsurface treatment for introducing the bacteria (Jackson et al in prep). In this paper we summarise the main effects of bacterial application by the subsurface method on grass grub populations in a series of trials carried out in Canterbury in 1987.

\section{METHODS}

The bacterial strain used in these trials, A2UC6, was selected for genetic stability in the laboratory and tested for pathogenicity by grass grub bioassay. The bacteria were produced for large scale field use by aerobic fermentation in a 1000 litre fermenter to a minimum concentration of $2 \times 10^{\%} / \mathrm{ml}$. The bacteria were applied in suspension as an unmodified fermenter broth. The viability of the suspension was determined by plate count and the bacterial rate determined by dilution of the broth with water. Bacteria were applied at rates of $4-90 \times 10^{13} / \mathrm{ha}$. All applications were made using 500 litres of mix per hectare through a modified Duncan triple disc drill (O'Callaghan et al 1987) at spacings of $150 \mathrm{~mm}$ (Trials 2 and 7) or $300 \mathrm{~mm}$. The bacteria were applied to pasture 3-6 years old. Trials were of split plot or randomised block design with at least four replicates of the bacterial treatment. Details of sites and individual trials are listed in Table 1.

The trials were assessed in May and again in September/October. Population estimates were made from at least five random spade samples $(150 \times 150 \times 150 \mathrm{~mm})$ per plot. Larvae were separated into developmental stages and categorised as either healthy or diseased on the basis of visual disease symptoms. A further assessment was made of four of the trials in May 1988 when larval population and incidence of disease were assessed.

Proc. 41st N.Z. Weed and Pest Control Conf. 
This summary includes treatments where bacterial rate exceeded $4 \times 10^{13} / \mathrm{ha}$. However, for simplicity, bacterial treatments in each trial are pooled despite some variation in time and rate of application. The results were analysed by analysis of variance or paired t-tests where appropriate.

TABLE 1: Site characteristics and application details for trials with $S$. entomophila for grass grub control.

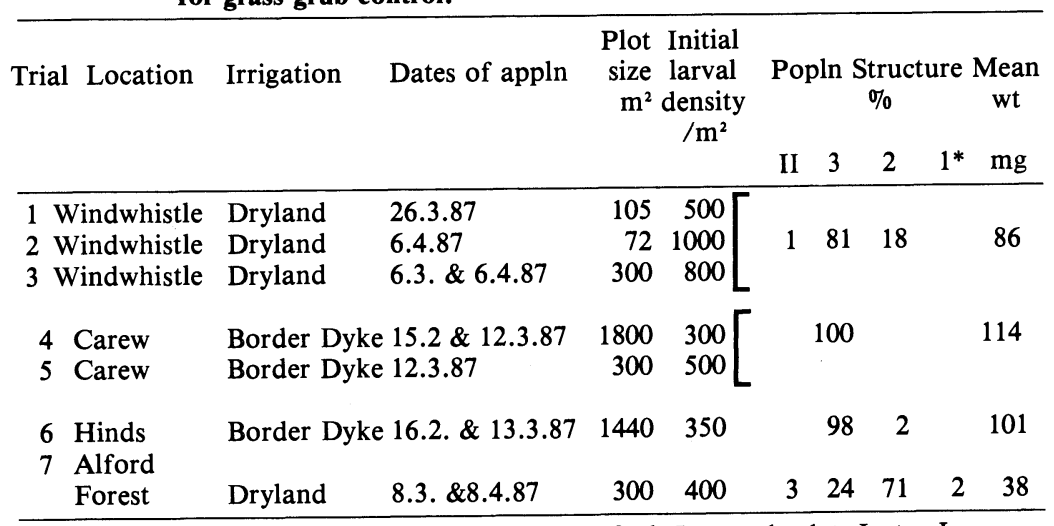

*II-Mature 2 year life cycle, 3-3rd. Instar, 2-2nd. Instar, 1-1st. Instar Larvae.

\section{RESULTS}

The effect of treatment on disease levels in May is shown in Fig 1. Bacterial application produced a significant $(\mathrm{P}<0.05)$ increase in disease in Trials $1,2,4,5$ and 6 . Variability in Trial 3 meant that the difference in percentage disease between treated and untreated was only significant at the $10 \%$ level. The low increase in disease in Trial 7 was not significant. The average level of disease in treated plots over all sites was $20 \%$, significantly $(P<0.05)$ higher than in untreated plots.

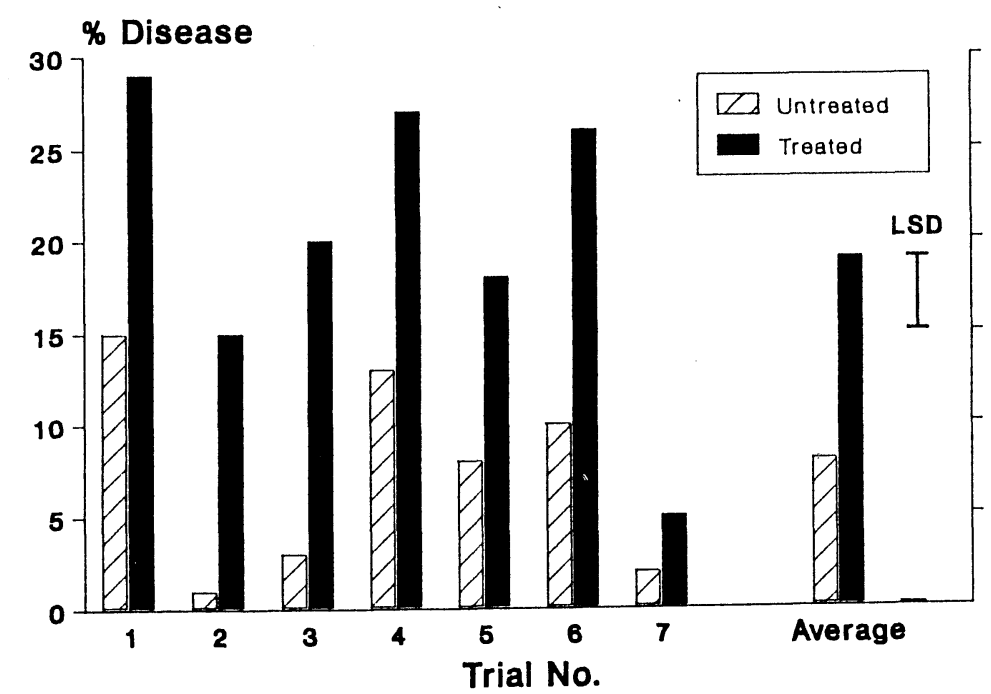

Fig. 1: Percentage of grass grub larvae infected with amber disease from 7 trials in Canterbury, May 1987. 
The effects of treatment at the end of the larval stage, September/October, are shown in Figure 2. Total populations were significantly reduced $\left(\begin{array}{ll}P & 0.05\end{array}\right)$ in Trials 1,5 and 6 and the numbers in the prepupal and pupal category were significantly reduced $(P<0.05)$ in Trials $2,3,5$ and 6 . The population difference in this category in Trial 1 was significant at the $10 \%$ level. The average population reduction over all sites was $22 \%$ while the reduction in the prepupal plus pupal category was $55 \%$.

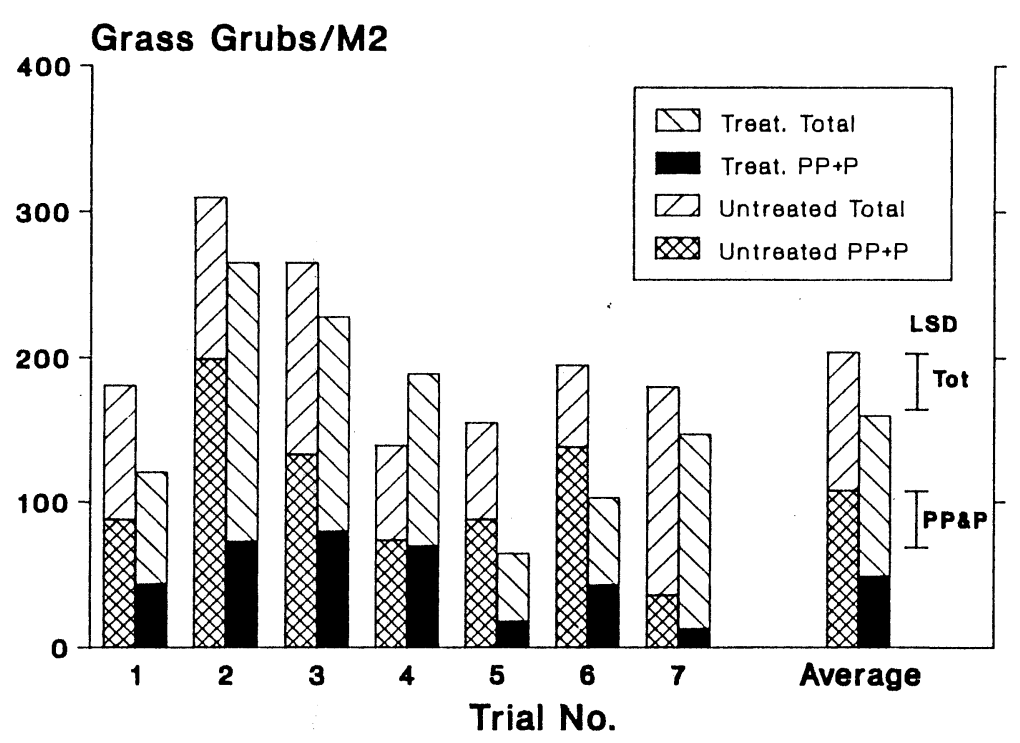

Fig. 2: Total numbers of larvae and numbers of prepupae and pupae from 7 trials in Canterbury, September/October 1987.

Assessment in April/May 1988 indicated that the treated populations were all below $200 / \mathrm{m}^{2}$ and were significantly $(P<0.05)$ lower than untreated at two of the four sites. Diseased larvae were recorded from both treated and untreated plots (Table 2).

TABLE 2: Effects of treatment with $S$. entomophila on grass grub populations and disease incidence 1 year after application.

\begin{tabular}{lcccc}
\hline & \multicolumn{4}{c}{ Number of larvae $/ \mathrm{m}^{2}-\%$ disease in brackets } \\
\cline { 2 - 5 } Site & 2 & 4 & 5 & 6 \\
Treated & $143(9)$ & $194(20)$ & $180(20)$ & $158(29)$ \\
Untreated & $284(14)$ & $313(40)$ & $329(42)$ & $177(28)$ \\
& ns & $*$ & $*$ & ns \\
\hline
\end{tabular}

\section{DISCUSSION}

The trial results show that $S$. entomophila was successfully established on six of the seven sites. The levels of disease appear low in comparison to those occurring in natural epizootics (Jackson 1984) but, because the bacteria were applied in drill rows at 150 or $300 \mathrm{~mm}$ spacing, initial infection took place only close to drill rows.

Although disease levels in May indicated that the bacteria had successfully established, measurement of the effects of that disease on the population was more difficult. Further assessments were made at the end of the larval stage in spring (Sept/Oct). By this time, pupation had commenced and more than $50 \%$ of the larvae in the untreated plots were in the pupal and prepupal category. The remainder of the 
larvae were classified as being mature and feeding, diseased, or small larvae in a two year life cycle. Total populations at this time showed an average decline of $22 \%$ as a result of bacterial application but it was obvious that many larvae, especially in the treated plots, would not complete their life cycle. The greatest differences between bacterial treated and untreated plots occurred in the prepupal and pupal category which reflects the effects of both disease and death on the population.

The average reduction in the pupal and prepupal category was $55 \%$ with significant $(P<0.10)$ population reductions recorded in five of the seven trials. Thus, the effects of the bacteria on the population are seen most clearly at the end of the season. Treatment can, however, have a marked effect on pasture within the season by reducing the feeding of the larvae (Jackson 1988). Neither total population nor the number of prepupae and pupae was significantly reduced in Trials 4 and 7 . Satisfactory levels of disease were recorded in May in Trial 4, where pasture damage in the treated plots was estimated at $12 \%$ compared with $40 \%$ in the untreated plots. The high levels of damage attracted the attention of rooks (Corvus frugilegus) and selective feeding by these birds in the damaged areas could have reduced the larval population to below that of the treated plots.

In Trial 7 the bacteria were applied to small second instar larvae. The majority $(85 \%)$ of the larvae remained as second or early third instars throughout the winter and subsequently entered a two year life cycle. Some disease was recorded in this population in spring. The limited effect obtained in this trial illustrates the importance of applying the bacteria when larvae are actively feeding. No visual damage was recorded on this site.

In May 1988 the mean population in the treated plots was $169 / \mathrm{m}^{2}, 39 \%$ below that in the untreated plots. Diseased larvae were collected from both treated and untreated plots (Table 2) indicating that there had been some spread of the disease from the treated plots or that natural disease had increased to a mean of $31 \%$.

This series of trials indicate that $S$. entomophila can be applied on a field scale to achieve successful control of grass grub. The results are comparable with those achieved with chemical insecticides (Carpenter et al 1981; East et al 1981) and the effects of treatment persist beyond the season of application. S. entomophila, therefore, appears to show promise for further development as a potential commercial biological control agent for grass grub.

\section{ACKNOWLEDGEMENTS}

Our thanks to NZAEI staff for assistance with bacterial production, Peck Lin Wong for quality assessment and Hamish Macnab and Ray van Schouten for assistance with field sampling. Also to Chris Dyson for data analysis and to the farmers involved for their cooperation.

\section{REFERENCES}

Carpenter, A., Wyeth, T.K. and Allan, P.J.T., 1981. Chemical control of grass grub in the southern North Island: results of 1977-79 trials. Proc. 34th N.Z. Weed and Pest Control Conf.: 225-228.

East, R., Willoughby, B.E., and Wrenn, N.R., 1981. Evaluation of the solid stream application technique for grass grub control in the northern North Island. Proc. 34th N.Z. Weed and Pest Control Conf.:229-233.

Grimont P.A.D., Jackson, T.A., Ageron, E., and Noonan, M.J., 1988. Serratia entomophila sp. nov., a species associated with amber disease in the New Zealand grass grub, Costelytra zealandica. International J. Systematic Bacteriology, 38:1-6.

Jackson, T.A., 1984. Honey disease, an indicator of population decline in grass grub. Proc. 37th N.Z. Weed and Pest Control Conf.:113-116.

Jackson, T.A., 1988. Effect of infection by the bacterium Serratia entomophila on feeding and pasture damage by grass grub larvae. Proc. 4Ist N.Z. Weed and Pest Control Conf.

Jackson, T.A., Pearson, J.F., and Stucki, G., 1986. Control of the grass grub, Costelytra zealandica (White) (Coleoptera:Scarabaeidae), by application of the bacteria Serratia spp. causing honey disease. Bull. Ent. Res. 76:69-76. 
O'Callaghan, M., Noonan, M.J., Broad, T.M. and Jackson, T.A., 1987. Methods for applying Serratia entomophila to pasture. Proc. 40th N.Z. Weed and Pest Control Conf.: 27-30.

Stucki, G., Jackson, T.A. and Noonan, M.J., 1984. Isolation and characterisation of Serratia strains pathogenic for larvae of the New Zealand grass grub Costelytra zealandica. N.Z. J. Sci., 27: 255-260.

Trought, T.E.T., Jackson, T.A. and French R.A., 1982. Incidence and transmission of a disease of grass grub (Costelytra zealandica) in Canterbury. N.Z. J. Exp. Agric. 10: 79-82. 